\title{
Władysław Padacz
}

\section{Postulator w procesach beatyfikacyjnych}

Prawo Kanoniczne : kwartalnik prawno-historyczny 5/1-2, 167-176

1962

Artykuł został zdigitalizowany i opracowany do udostępnienia w internecie przez Muzeum Historii Polski w ramach prac podejmowanych na rzecz zapewnienia otwartego, powszechnego i trwałego dostępu do polskiego dorobku naukowego i kulturalnego. Artykuł jest umieszczony w kolekcji cyfrowej bazhum.muzhp.pl, gromadzącej zawartość polskich czasopism humanistycznych i społecznych.

Tekst jest udostępniony do wykorzystania w ramach dozwolonego użytku. 


\section{KS. WEADYSEAW P A D A C Z}

\section{POSTULATOR W PROCESACH BEATYFIKACYJNYCH}

1. Rzut historyczny. - Wraz z instytucja promotora wiary rozwijała się stopniowo inna, mianowicie postulatora sprawy beatyfikacyjnej lub kanonizacyjnej. Samego wszakże wyrazu ,postulator" nie używano w dawnym procesie kanonicznym ${ }^{1}$, aczkolwiek czynność postulatora przyjęta została, podobnie jak wiele innych, $z$ prawa rzymskiego ${ }^{2}$ do zwyczajnego trybu postępowania zarówno $w$ sprawach sądowych jak i administracyjnych ${ }^{3}$. W sprawach zaś kanonizacyjnych instytucja postulacji, jako prośby do Stolicy Apostolskiej osoby prawnej lub fizycznej o wyniesienie na ołtarze zmarłego w opinii świętości wyznawcy Chrystusa, występuje sporadycznie w wiekach średnich. Osobę wnoszącą prośbę określano mianem ,procurator", chociaż z akt niektórych spraw można sądzić, że tę samą nazwę dawano przedstawicielowi osoby prawnej, czyli dzisiejszemu postulatorowi ${ }^{4}$.

Dopiero tak bardzo znany $w$ rozwoju prawa beatyfikacyjnego i kanonizacyjnego papież Urban VIII w swej wiekopomnej bulli „Coelestis Hierusalem" z dnia 5 lipca 1634 r. użył wyrazu postulator, określając nim urząd, który ma pełnić

${ }^{1}$ Po raz pierwszy wyrazu tego uży $\mathrm{H}$ os tien s is H., Summa Aurea, Venetiis 1580,377 .

2 Por. D. $46,8,21 ;-27,7,2 ;-36,1,6$.

3 Por. 2. C. III, q. 7; - W i l a n ow k i B., Rozwó j historyczny procesu kanonicznego, Wilno 1929, 1, 115.

4 Por. Acta Sanctorum, III, 470; - IX, 77 ns; - Ben XIV, De servorum Dei beatificatione et beatorum canonizatione, Romae 1747, 2, 47,6 ; - B I a her D., The ordinary processes in causes of beatification and canonization, Washington 1949, 22. 
osoba działająca i występująca jako pełnomocnik w konkretnej sprawie beatyfikacyjnej ${ }^{5}$. Bulla określiła ściśle, że żadna nowa sprawa nie może być prowadzona bez dokładnego wyświetlenia, czy kandydatowi nie oddaje się już czci publicznej, bez zgody kompetentnej władzy duchownej. Właśnie głównym zadaniem postulatora było zbadanie, czy wszystkie zarządzenia papieskie poprzednio wydane, były pod tym względem skrupulatnie zachowane. Podobnie przy sądowym badaniu istnienia rozgłosu świętości, cnót i cudów sługi Bożego postulator miał czuwać, żeby odpowiednie dowody były doręczone sędziom w odpowiednim czasie.

W chwili wydania bulli istniał już długi poczet sług Bożych, którym oddawano cześć publiczną. Papież przeto zdecydował, że należy zweryfikować ich kult, przeprowadzając proces, w którym trzeba zbadać, od jak dawna wierni taką właśnie cześć okazują. Jeżeli okaże się, że początek kultu publicznego sięga przynajmniej roku 1534, to należy pozostawić ich $\mathrm{w}$ katalogu świętych. W takim procesie występował również postulator, zbierając i przedkỉadając trybunałowi beatyfikacyjnemu konieczne dowody.

Od czasów Urbana VIII następuje stały rozwój urzędu postulatora. Papież Aleksander VII wydaje dekret z dnia 9 kwietnia 1661 r. o funduszach i opłatach w procesie beatyfikacyjnym i kanonizacyjnym. Regulowaniem tych spraw materialnych mają zajmować się postulatorzy ${ }^{6}$.

Innocenty XI dnia 15 października 1678 r. upoważnia postulatora do przedstawienia listy świadków, wybierania adwokata z grona konsystorialnych do obrony prawnej sprawy beatyfikacyjnej, składania orzeczeń lekarskich dotyczących cudownych uzdrowien ?.

Za czasów najznakomitszego znawcy prawa beatyfikacyjnego i kanonizacyjnego, Benedykta XIV, ukazało się szereg dokumentów papieskich, mających doniosłe znaczenie dla procesów beatyfikacyjnych. $\mathrm{Z}$ tych dokumentów bezpośrednio do-

" Gasparri P., Codicis iuris canonici fontes, I, 218.

- Por. Ben. XIV, dz. cyt., 1. App. 14.

7 Por. Fontes, VII, n. 5626. 
tyczy postulatora dekret z dnia 17 lipca 1744 r. „Cum ex relatione", określający ilość świadków i cudów koniecznych do prowadzenia procesu beatyfikacyjnego i kanonizacyjnego. Zarówno zgłaszanie listy świadków, jak też cudów dokładnie opisanych, należało do postulatora ,stąd właśnie dla niego wspomniany dekret stanowi jeden $\mathrm{z}$ najważniejszych dokumentów papieskich ${ }^{8}$. Wiekopomną zasługą papieża Benedykta XIV jest $\mathrm{m}$. in. to, że oprócz licznych dekretów pod różnymi nazwami występujących, a dotyczących spraw beatyfikacyjnych i kanonizacyjnych, pozostawil po sobie dzieło pisane: „De servorum Dei beatificatione et beatorum canonizatione". Dzieło to, aczkolwiek wydane jako praca prywatna, jednakże biorąc pod uwagę autorytet papieża jako kanonisty, $w$ tej dziedzinie stanowi normę postępowania $w$ praktyce trybunalów beatyfikacyjnych i osób z nimi związanych. I właśnie w księdze pierwszej, w rozdziale $46 \mathrm{n} .13$ Benedykt XIV obszernie wykłada, kim jest postulator $\mathrm{w}$ procesach o wyniesienie świątobliwych osób na ołtarz. Zainteresowana bowiem osoba prawna, jako strona powodowa (actor), daje inicjatywę do wszczęcia procesu beatyfikacyjnego i pokrywa konieczne koszta, konkretnie jednak nie wiele może działać w przeprowadzeniu toku postępowania beatyfikacyjnego albo kanonizacyjnego; wszystko natomiast załatwia pełnomocnik, wyznaczony przez tę właśnie osobę.

2. Prawo kodeksowe. - Kodeks Prawa Kanonicznego poszedł za przyjętą praktyką i nauką głoszoną przez Benedykta XIV, określając powoda jako osobę prawną lub fizyczną, pozostającą $\mathrm{w}$ jedności $\mathrm{z}$ Kościołem, która składa umotywowaną prośbę do kompetentnego ordynariusza o wszczęcie procesu beatyfikacyjnego świątobliwego kandydata na oltarze ${ }^{9}$. Samo prowadzenie sprawy wymaga jednak stałego i pilnego czuwania nad tokiem postępowania. Bardzo rzadko bowiem się zdarza, żeby powód nie bacząc na skomplikowaną procedurę, decydował się na osobiste prowadzenie sprawy beatyfikacyjnej; czyn-

${ }^{8}$ Por. Fontes, I, n. 343.

- Kan. $2003 \S 1$. 
ność tę wykonuje osoba upoważniona przez powoda, zwana $\mathrm{w}$ prawie beatyfikacyjnym postulatorem, posiadająca szczególne kwalifikacje ${ }^{10}$. Przy mianowaniu postulatora należy zachować wszelkie przepisy odnoszące się zarówno do osoby pełnomocnika jak i do formy pełnomocnictwa ${ }^{11}$. Postulator występujący bez szczególnego lub też na podstawie wadliwie sporządzonego pełnomocnictwa, naraża na nieważność cały tok postępowania beatyfikacyjnego.

Należy również wziąć pod uwage różnicę, zachodzącą między procesem apostolskim a trzema diecezjalnymi: w procesach bowiem diecezjalnych ordynariusz, o ile jest powodem, sam mianuje postulatora, w apostolskim zaś - postulator, zamieszkujący w Rzymie ${ }^{12}$, daje stosowne upoważnienie kapłanowi tej diecezji, na której terenie odbywa się proces.

Co się tyczy zgromadzeń zakonnych żeńskich, zawsze stosownie do przepisu kan. $2004 \S 1$ - mają one działać przez pełnomocnika, mianowanego przez kompetentną władzę zakonną ${ }^{13}$. Rzeczą jest jasną, że kapłan, bez względu na to, czy jest kapłanem zakonnym, czy diecezjalnym, nie-może przyjąć ofiarowanego mu urzędu bez zgody właściwego ordynariusza.

Jeżeli biskup, występując jako powód, wszczyna proces na terenie swej diecezji, wówczas sam mianuje postulatora, chociażby kandydat na ołtarze należał do zgromadzenia zakonnego.

Niektóre zakony męskie posiadają w Rzymie stałych postulatorów, którzy, w razie braku spraw beatyfikacyjnych lub kanonizacyjnych własnego zakonu, chętnie podejmują się występować jako postulatorzy w sprawach innych zakonów, zgromadzeń lub diecezji ${ }^{14}$.

3. Przymioty postulatora. - Stosownie do przepisu kan. 2004 $\S 3$ postulator, żeby ważnie mógł spełniać poruczone mu zadania, powinien być kapłanem diecezjalnym lub zakonnym.

\footnotetext{
10 Kan. $2003 \S 2$.

${ }^{11} \mathrm{Kan} .1659$; - 2006; - G i ove R., Note sulle discussioni intorno alla validita dei processi, Roma 1940.

12 Kan. 2004 \& 3.

13 Por. B laher D., dz. cyt. 73.

14 Por. Blacher D., dz. cyt., 75.
} 
Przed Kodeksem warunek ten nie był ani wymagany ani nakazany dekretami, aczkolwiek dawniejsza praktyka nie wykazywała pod tym względem odchyleń od dzisiejszej. Powody, którymi kieruje się prawodawca określając, że tylko osoba stanu kapłańskiego może być postulatorem, wynikają z kwalifikacji, jakie są potrzebne do piastowania tego właśnie urzędu.

a) Konstytucja Apostolska „Coelestis Hierusalem", ustanawiając stały urząd postulatora, nie wyszczególniała jego kwalifikacji. Natura jednak samego urzędu oraz praktyka Kongregacji Obrzędów, stawiająca duże wymagania pełnomocnikom w sprawach beatyfikacyjnych i kanonizacyjnych ${ }^{15}$ żądały posiadania przez postulatora szeregu cnót i przymiotów. Potwierdza to Benedykt XIV, który wyjaśnia, że postulator powinien się odznaczać $w$ odpowiednio wysokim stopniu roztropnością ${ }^{16}$, troskliwością ${ }^{17}$ i pilnością ${ }^{18} \mathrm{~W}$ prowadzeniu sprawy oraz uczciwością ${ }^{19}$.

b) Kodeks Prawa Kanonicznego, aczkolwiek wprost o kwalifikacjach i zaletach postulatora nie wspomina, to jednak z nacisku jaki kładzie na osobę pełnomocnika, latwo można wnosić o intencji prawodawcy. W pierwszym rzędzie każdego postulatora i wicepostulatora ma cechować głęboka wiedza. $Z$ zadań bowiem, jakich się podejmują, płyną wymagania: każda sprawa beatyfikacyjna jest trudna do przeprowadzenia; zbieranie dowodów na heroiczność cnót, na świętość życia i na istnienie cudów, a następnie rzeczowa i bezstronna ocena tych dowodów, wymaga nieprzeciętnej znajomości prawa, teologii, psychologii, ascetyki katolickiej. Skoro sędziowie w procesach beatyfikacyjnych i kanonizacyjnych odznaczać się muszą posiadaniem szczególnych przymiotów, to przynajmniej równorzędne kwalifikacje powinien posiadać postulator, a więc być

15 Por. Codex pro postulatoribus, 27; - B lacher D., dz. cyt., 75 ns.

16 Por. Ben. XIV, dz. cyt., II, 53, 4.

17 Por. Ben. XIV, dz. cyt., II, 1, 13.

18 Por. Ben. XIV, dz. cyt., II, 5, 7.

19 Por. Benn. XIV, dz. cyt., II, 6, 9. 
kapłanem z ukończonymi studiami teologicznymi i prawniczymi ${ }^{20}$.

c) Procedura beatyfikacyjna, jako wielce skomplikowana, wymaga szczególnej znajomości prawa beatyfikacyjnego i to zarówno na podstawie uzyskanego dyplomu, jak i praktyki. Stąd właśnie nie każdy kanonista może zostać postulatorem lub wicepostulatorem, ale tylko taki, który jest szczegółowo obeznany z kanonami 1999_2041, oraz lubi poświęcać czas na osobiste dalsze studia i badania.

4. Przysięgi skladane przez postulatora. - Obowiązek składania przysięgi na słuszność sprawy ${ }^{21}$ przez postulatora na początku procesów informacyjnego oraz o braku kultu należy ując i wyjaśnić osobno, ponieważ jej treść jest charakterystyczna dla zadań, jakie ma wypełnić postulator. Zaraz na pierwszej sesji, gdy ordynariusz urzędowo powołuje trybunał i cdbiera od niego potrójną przysięgę, postulator składa wówczas tylko jedną, ale znamienną, znaną już w prawie rzymskim jako iuramentum calumniae, czyli przysięge na słuszność sprawy ${ }^{22}$. W przysiędze tej chodzi o to, żeby postulator uroczyście stwierdził wobec Boga, że wierząc w słuszność sprawy przez siebie prowadzonej, nigdy nie przedstawi jako prawdy tego, co w swej istocie jest fałszem. W szczególności postulator zobowiązuje się, że:

a) nie przedstawi fałszywych dowodów,

b) nie będzie działał podstępnie lub przekupstwem,

c) będzie mówił prawdę,

d) nie będzie przewlekał sprawy,

e) nie będzie ani ubocznie ani wprost tak działał, żeby przeszkodzić ujawnieniu obiektywnej prawdy.

Ogólnie biorąc, należy zaznaczyć, że treść przysięgi jest tak ujęta, żeby zabezpieczyć bezstronne prowadzenie sprawy nie

20 Por. Kan. $1573 \S 4 ;-1574 \S 1 ;-1657$; - Coronata A. M., Institutiones Iuris Canonici, Romae 1948, 3, 456.

${ }^{21}$ Kan. 2037 \$ 4 . Tekst rysięgi podaja $\mathrm{m}$. in. Codex pro postulatoribus 85, oraz Machejek-Padacz, Sprawy beatyfikacyjne na terenie diecezji, Poznań 1957, 364.

${ }_{22} 1$, II, 4 in $6^{\circ}$; - Ben. XIV, dz. cyt. $2,48,3$. 
tylko przez powoda, ale i przez postulatora. Jemu samemu ma też iuramentum calumniae przypominać, że $\mathrm{w}$ pracy ma się kierować pobudkami nadprzyrodzonymi, wykluczając wszelkie postępowanie oparte na względach lub wyrachowaniach ludzkich ${ }^{23}$.

Samo wyrażenie „kalumnia" w języku polskim w potocznym rozumieniu ma znaczenie ujemne, jednakże omowne tłumaczenie jako „słuszność sprawy” odjęło całą ostrość wyrazowi łacińskiemu.

Oprócz przysięgi na słuszność sprawy postulator składa jeszcze inne, zależnie od procesu, który ma się odbywać, a więc np. na pierwszej sesji postępowania zbierania pism postulator przysięga, że pilnie będzie poszukiwał pism sługi Bożego ${ }^{24}$.

5. Prawa i obowiązki postulatora. - Kapłan, któremu zaproponowano objęcie urzędu postulatora lub wicepostulatora, po-winien:

a) $\mathrm{w}$ pierwszym rzędzie zapoznać się z postacią, z życiem, z działalnością i oznakami świętości kandydata na ołtarze;

b) zorientować się, jaką drogą miałby prowadzić proces, tj. zwyczajną, nadzwyczajną czy historyczną;

O ile następnie dojdzie do wniosku, że istnieją prawne i faktyczne podstawy wszczęcia procesu informacyjnego, może urząd przyjąć. Od tej chwili ciąży na nim szereg obowiązków. Postulator przeto otrzymawszy pelnomocnictwo od biskupa lub postulatora w Rzymie, musi pamiętać, że jego zasadniczym obowiązkiem jest $\mathrm{w}$ zastępstwie i $z$ upoważnienia powoda prowadzić całą sprawę w tym szerokim zakresie ${ }^{25}$, który przewiduja konkretne przepisy prawa beatyfikacyjnego i kanonizacyjnego. W szczególności zaś ma pamiętać, że do jego zađań należy:

a) przedstawić biskupowi ordynariuszowi listę kandydatów na członków trybunału, na promotora wiary oraz, $w$ razie potrzeby, na ich zastępców;

23 Por. B 1 a h e r D., dz. cyt., 170 ; - In d e 1 i c a to S., Il processo apostolico di beatificatione, Roma 1945, 34.

24 Kan. 2047 § 1.

${ }_{25}$ Kan. $2007 \S 1$. B laher D., dz. cyt., 79 nss.; - M a chejek-P ad a c z, dz. cyt., 196 nss. 
b) przygotować artykuły ${ }^{26}$;

c) $w$ porozumieniu $z$ kanclerzem kurii przygotować pierwsze posiedzenie oraz niezbędne formularze i teksty;

d) wręczyć artykuły kandydatowi na promotora wiary, żeby ten zdążył sporządzić pytania na sesję ad acta primordialia;

e) starać się o niezbędne fundusze na prowadzenie pro-cesu ${ }^{27}$;

f) o ile sprawa została wniesiona po 30 latach od śmierci sługi Bożego, postulator ma podać do protokółu na pierwszej sesji przyczyny, które spowodowały przekroczenie terminu prekluzyjnego ${ }^{28}$;

g) poszukać świadków, a spośród nich wybrać najodpowiedniejszych; postulator nie może przedstawiać wszystkich zgłaszających się, ale tylko tych, którzy mogą podać charakterystyczne szczegóły, dotyczące cnót sługi Bożego lub cudów, zdziałanych za jego pośrednictwem ${ }^{29}$;

h) wręczyć w odpowiednim czasie świadkom artykuły, wyjaśnić ich znaczenie, ale nie sugerować odpowiedzi;

i) czuwać, żeby wyznaczeni świadkowie zjawili się na określony termin, a oprócz tego, $\mathrm{w}$ razie potrzeby, pokrywać koszta ich podróży;

j) zgłosić trybunałowi uzupełniających świadków, którzy mogą podać nowe okoliczności i fakty, nieznane innym świadkom, a posiadające znaczenie dla całości sprawy;

k) w procesie o braku kultu prosić trybunał o wydanie wyroku;

1) gdyby $w$ czasie procesu informacyjnego zdarzyły sie cudowne uzdrowienia, dokonane za pośrednictwem kandydata na ołtarze, postulator ma obowiązek zbadania ich, a następnie osobnym pismem przedstawienia swych spostrzeżeń i wniosków trybunałowi, który poweźmie dalsze decyzje;

${ }^{26}$ Kan. 2007 nr. 4; - Codex pro postulatoribus, 19; - Ben. XIV, dz. cyt. II, 49, 7; - II, 44, 2; - B I a her D., dz. cyt., 104 nss.; - Resoconti manoscritti delle relationi lette nelle riunioni di studio dell anno 1939, Roma, 1939.

27 Kan. 2007 n. 2.

${ }^{28} \mathrm{Kan} .2049$.

${ }^{29}$ Kan. 2007 n. 4 ; - 2024; - 2057; - Codex pro postulatoribus, 51. 
ł) składać prośbe do ordynariusza o rozpoczęcie sądowego zbierania pism. Dla przyśpieszenia toku postępowania sam postara się skutecznie pomagać trybunałowi;

m) przy rozpoznaniu grobu sługi Bożego pilnie obserwować, gdyby okazała się konieczność ekshumacji, poprosić o nią kompetentnego biskupa;

n) na życzenie trybunału przedkładać żądane dokumenty :0;

o) po publikacji pilnie przeczytać akta sprawy i zanotować ważniejsze spostrzeżenia;

p) przygotować na sesję końcową dwie teczki o ustalonym wzorze na akta oryginalne i dwie inne na odpisy oraz niezbędne materiały piśmienne;

r) brać czynny udział w sesji końcowej każdego procesu, pomagając przy zmknięciu akt i przy ich opieczętowaniu;

s) przy zakończeniu procesu, na sesji otrzymać z rąk ordynariusza odpis akt i przesłać go do Rzymu ${ }^{31}$

t) przygotować pismo do postulatora sprawy sługi Bożego, uprzedzając o ewentualnych trudnościach, zastrzeżeniach i usterkach, których nie dało się uniknąć;

Prócz tego gorliwy postulator ma pilnie czuwać, by proces możliwie szybko się odbywał, dlatego powinien korzystać $z$ przysługujących mu uprawnień, a mianowicie:

a) być $\mathrm{w}$ stałym kontakcie $\mathrm{z}$ przewodniczącym trybunału i z promotorem wiary;

b) w razie napotykanych nieuzasadnionych trudności dyskretnie zwracać się z prośbą o interwencję u biskupa, który mianował trybunał;

c) brać udział $w$ każdej sesji od chwili złożenia przysięgi przez świadka;

d) uczestniczyć w sesjach, na których odbywa się porównanie odpisu akt $z$ orginałem; da mu to sposobność powtórnego usłyszenia zeznań świadków i nabrania dokładnego poglądu na całość zeznań i zebranych dowodów; w razie potrzeby powiadamia o swoich spostrzeżeniach postulatora sprawy w Rzymie;

\footnotetext{
${ }^{30}$ Kan. 2007 n. 3; - 2034; - In de $1 \mathrm{i}$ c a to S., Le basi giuridiche del processo di beatificazione, Roma 1944, 108.

31 Kan. 2056; - 2063; - 2064.
} 
e) prosić kompetentnego biskupa o uzupelnienie trybunału, o ile zachodzi potrzeba lub koniecznośc;

Wymienione prawa i obowiązki nie wyczerpują liczby tych, które dotyczą zadań postulatora konkretnej sprawy beatyfikacyjnej lub kanonizacyjnej. Roztropny i przewidujący postulator w oparciu o przepis kan. 2007 n. 1 zawsze znajdzie sposobność, żeby, nie naruszając ani norm kanonicznych ani złożonej przysięgi, zjawić się $\mathrm{w}$ odpowiednim czasie i udzielić stosownej pomocy trybunałowi. Treść bowiem wspomnianego kanonu jest dowodem, że urząd postulatora wcale nie skostniał w ciągu wieków, ale podlega dalszej ewolucji. Wraz bowiem $z$ jednej strony $\mathrm{z}$ ustaleniem zasad procedury beatyfikacyjnej i kanonizacyjnej, a $z$ drugiej $-z$ rozwojem zakresu spraw i dróg prowadzących do kanonicznego stwierdzenia świętości, urząd postulatora, podobnie jak promotora, nabiera żywotności i prawnej wyrazistości. 